\title{
大西一成 学位論文審査要旨
}

主査岸本拓治

副主査山元修

同黒 沢 洋一

\section{主論文}

Adverse health effects of Asian dust particles and heavy metals in Japan (黄砂粒子と重金属の健康への有害作用)

(著者 : 大西一成、大谷眞二、吉田篤史、穆 浩生、黒沢洋一)

平成24年 Asia-Pacific Journal of Public Health 掲載予定 


\section{学 位 論 文 要 旨}

\section{Adverse health effects of Asian dust particles and heavy metals in Japan （黄砂粒子と重金属の健康への有害作用）}

黄砂現象は、モンゴルや中国の乾燥地や半乾燥地における森林減少、土壌の劣化、砂漠 化の影響により、近年黄砂の発生頻度や規模が増大している。黄砂には、石英、長石、雲 母などの鉱物が多く含まれているが、飛来途中に大気污染物質を取り込んでおり土䁃起源 ではない重金属や硫酸イオン、硝酸イオンも一緒に飛来していることが指摘されているた め健康影響について懸念されている。本論文では、黄砂飛来時に同時に曝露される環境因 子（重金属・黄砂・花粉・ $\mathrm{SO}_{2} \cdot \mathrm{NO}_{2}$ ・気温・湿度・気圧）と米子市住民の自覚症状を用い て多変量解析を行い、黄砂の何が、どのような健康症状へ影響を及ぼすのかを調査した。

\section{方 法}

2009年2月に、米子市住民健常人54人に、日記式の自覚症状の調査を行った。質問票は鼻、 眼、呼吸器、皮膚症状の程度についてビジュアルアナログスケールを用いた。同期間の米 子市に飛来した黄砂は、ハイボリュームエアサンプラーを用いて採取し、誘導結合プラズ マ発光分光分析法にて重金属元素を分析した。黄砂の程度の指標としてしばしば用いられ る大気中の10 $\mu$ m以下の浮遊粒子状物質SPM（Suspended Particulate Matter）の濃度、花 粉、大気污染物質として窒素酸化物（NOx）、硫黄酸化物（SOx）のデータは、鳥取県衛生 環境研究所から提供を受けた。また、気候データは気象庁から得て、統計学的検討にはt 検定、多変量解析を用いた。黄砂の曝露の次の日の黄砂の健康影響の可能性を考慮し、前 日の環境因子を考慮して行った。

\section{結 果}

2009年2月は、気象庁が判定した黄砂日が6日間あった。鼻と眼の症状には、花粉が強く 影響を示していた。（黄砂）SPMは、曝露翌日の皮膚の症状と強い関係があった。土壤由来 金属（Fe、Ca、Al） と污染物質由来金属（Pb、Cr、Mn、Ni、Zn）はともに、非黄砂日と比 ベて黄砂日に有意に上昇していた。中でも、Niが皮膚スコアと強く相関を示していた。 
黄砂の健康影響の研究はまだ始まったばかりである。海外では、黄砂日における喘息患 者の病院受診の増加、鼻炎や結膜炎症状の悪化が報告されている。日本では、小児喘息の 悪化が報告されている。今回の調查では、黄砂に含まれるNiが、曝露した翌日に皮膚症状 を引き起こすことが示唆された。今回の対象者は、健常人であるため、特に呼吸器のスコ アが小さかったが、喘息やアレルギー素因を持つ対象者でこの調査を行った場合、呼吸器 の症状への影響が示唆される可能性がある。本研究の限界として、対象者が室内労働者で あること、個人が直接曝露された環境因子の量は測定されていないことなどがあげられる。 今後、環境因子に生物由来成分を追加して黄砂の健康影響を検討する必要がある。

\section{結 論}

健常人において、黄砂に曝露した翌日に黄砂に含まれるNiによって皮膚症状を引き起こ す可能性が示唆された。今後、黄砂の健康影響を調查する際に、黄砂に含まれる成分を加 味して行う事が重要であり、モデル解析や様々な環境因子を加味して調査を行うことが期 待される。 